\title{
Catalysts under Controlled Atmospheres in the Transmission Electron Microscope
}

Hansen, Thomas Willum; Masini, Federico; Deiana, Davide; Nielsen, Jane Hvolbæk; Chorkendorff, Ib; Wagner, Jakob Birkedal

Published in:

Proceedings of the 3rd International Symposium on Advanced Electron Microscopy for Catalysis

Publication date:

2014

Document Version

Publisher's PDF, also known as Version of record

Link back to DTU Orbit

Citation (APA):

Hansen, T. W., Masini, F., Deiana, D., Nielsen, J. H., Chorkendorff, I., \& Wagner, J. B. (2014). Catalysts under Controlled Atmospheres in the Transmission Electron Microscope. In Proceedings of the 3rd International Symposium on Advanced Electron Microscopy for Catalysis

\section{General rights}

Copyright and moral rights for the publications made accessible in the public portal are retained by the authors and/or other copyright owners and it is a condition of accessing publications that users recognise and abide by the legal requirements associated with these rights.

- Users may download and print one copy of any publication from the public portal for the purpose of private study or research.

- You may not further distribute the material or use it for any profit-making activity or commercial gain

- You may freely distribute the URL identifying the publication in the public portal 


\title{
Catalysts under Controlled Atmospheres in the Transmission Electron Microscope
}

\author{
Thomas W. Hansen ${ }^{1,}$, Federico Masini ${ }^{2}$, Davide Deiana ${ }^{1}$, Jane H. Nielsen ${ }^{2}$ and Ib Chorkendorff ${ }^{2}$ and \\ Jakob B. Wagner ${ }^{1}$ \\ ${ }^{1}$ Center for Electron Nanoscopy, Technical University of Denmark, DK-2800 Kgs. Lyngby, Denmark \\ ${ }^{2}$ Center for Individual Nanoparticle Functionality (CINF), Technical University of Denmark, DK-2800 \\ Kgs. Lyngby, Denmark \\ *: presenting author, email: twh@cen.dtu.dk
}

Electron microscopy provides a highly versatile platform for the characterization of supported metal nanoparticles for heterogeneous catalysis. With high spatial resolution as well as spectroscopic capabilities, the EM platform can characterize materials in detail. With the addition of environmental capabilities, the microscope can even probe samples under reactive environments. Recent developments include high solid angle EDX detectors, which can rapidly acquire high-resolution elemental maps, and micro electro-mechanical systems (MEMS) based heating holders that can heat samples at very high rates with only little spatial drift.

As an example, we will utilize the versatility of the environmental TEM to study the morphology of ruthenium nanoparticles under a reactive environment. Ruthenium have been found to effectively catalyze the methanation of carbon monoxide to methane ${ }^{1}$. In order to further investigate the effect of annealing on particle morphology, size selected ruthenium nanoparticles were prepared using sputtering and aggregation technique and time of flight mass selection ${ }^{2}$. The samples were studied in an environmental transmission electron microscope (FEI Titan 80-300 ETEM $^{3}$ ) under both hydrogen and a reactive mixture of $\mathrm{CO}$ and $\mathrm{H}_{2}$.

For ETEM experiments, the size-selected ruthenium nanoparticles were collected on an Echip (Protochips Inc.) coated with a silicon nitride membrane within the cluster source. The sample was first imaged in vacuum at room temperature where the NPs appeared both as multi-domain as well as single crystalline nanoparticles with a jagged surface structure (Fig. 1 left). The sample was then heated to reaction temperature $\left(427^{\circ} \mathrm{C}\right)$ where the jagged surface structure to some extent was lost (Fig. 1 middle). After reaching the reaction temperature, the sample was exposed to a 1:10 mixture of $\mathrm{CO}$ and $\mathrm{H}_{2}$ at 230 $\mathrm{Pa}$ and the sample was again imaged. At this stage, most NPs appeared as almost single-crystalline nanoparticles (Fig. 1 right) and the surface has lost the jagged structure compared to the initial state.

This study shows the dynamic nature of catalyst nanoparticles and that, in order to investigate the active state of catalyst samples, they must be imaged under relevant conditions.
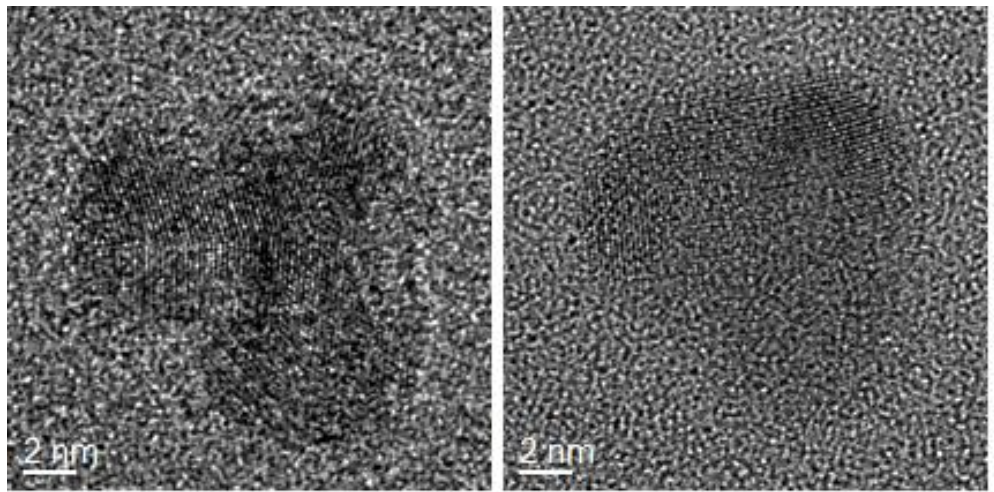

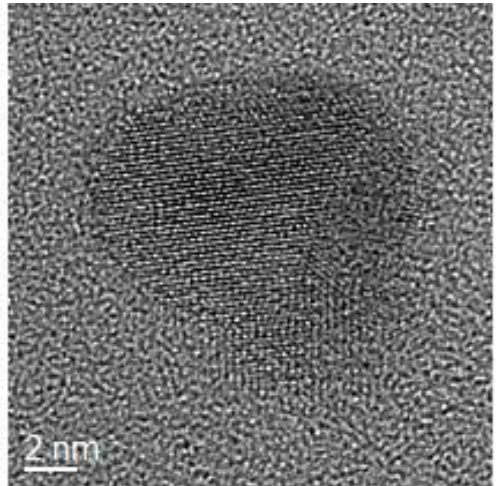

Figure 1 Left: Room temperature, vacuum; middle: $427^{\circ} \mathrm{C}$, vacuum; right: $427^{\circ} \mathrm{C} 230$ Pa 1:10

References

1) Lee, H.-I.; White, J. M., J. Catal. 1980; 63: 261-264.

2) Masini, F.; Strebel, C. E.; McCarthy, D. N.; Nierhoff, A. U. F.; Kehres, J.; Fiordaliso, E. M.; Nielsen, J. H.; Chorkendorff, I., J. Catal. 2013; 308: 282-290.

3) Hansen, T. W.; Wagner, J. B.; Dunin-Borkowski, R. E., Mater. Sci. Technol. 2010; 26: 1338-1344. 